\title{
Increasing Shipyard Competitiveness Through Fiscal Policy Government and Human Resources, Case Studies Indonesia
}

\author{
Catur Wahyu Nugroho, ${ }^{1, a}$, Verlyna Astriya Suharyanti', ${ }^{2, b}$, and Raja Oloan Saut Gurning,,c,* \\ ${ }^{1}$ Marine Engineering Department, Sepuluh Nopember Institute of Technology, Surabaya, Indonesia \\ ${ }^{2}$ Human Resource Development, PT. SCG Pipe and Precast, Sidoarjo, Indonesia \\ a.caturwahyun88@gmail.com, b.verlynas@scg.com,c.sautgurning2@gmail.com \\ *sautgurning2@gmail.com
}

Keywords: Shipbuilding, Fiscal Policy, Government, Competitiveness, Human Resources.

Abstract: Shipbuilding is an industry that can improve the economy of a country. A lot of shipyards should be on increasing the competitiveness of shipbuilding. The role of government such as fiscal, financial, and human resources are some of the factors. The influence government's fiscal policy and human resources competitiveness of shipbuilding will discuss. The case studies carried out in the country of Indonesia. Literature several journals use as the reference to competing Indonesia shipyards. Results showed an implementation government's fiscal policy and human resources in Indonesia condition. Thus, implementation fiscal policy and human resource development need to improve the competitiveness.

\section{Introduction}

Shipbuilding is industries to produce products ships according to customer requirements. Yet, shipbuilding not only builds new ships but also maintenance and repair.

Shipbuilding consist of several types, Building dock shipbuilding, Shipbuilding Dock Repair, and General Engineering Shipbuilding. Building Dock Shipbuilding is a shipyard that is a function to build new ships. Repair Dock Shipbuilding is a shipyard to perform maintenance and repair of the ship. Engineering shipbuilding is a type of shipyard build equipment or facilities. That function to assist the performance of ships at sea, among others: fuel tanks and so on.

The case studies carried out in Indonesia, which has more sea than land. With a total area of 5.29325 million $\mathrm{km} 2,64.97 \%$ of the total area is the sea. Indonesia has 250 units shipyard which has an output of 12 million DWT / year, use of $85 \%$ and $70 \%$ of the domestic market. Of the 250 units, 160 units of the shipyard are buildings the capacity of 1.2 million DWT Shipyard/year, use was $45 \%$. Of the 250 units shipyard in Indonesia, spread from west to east. Spread of the distribution, Java $37 \%$, Sumatra Island $26 \%, 25 \%$ on the island of Borneo and the rest scattered in eastern Indonesia. 


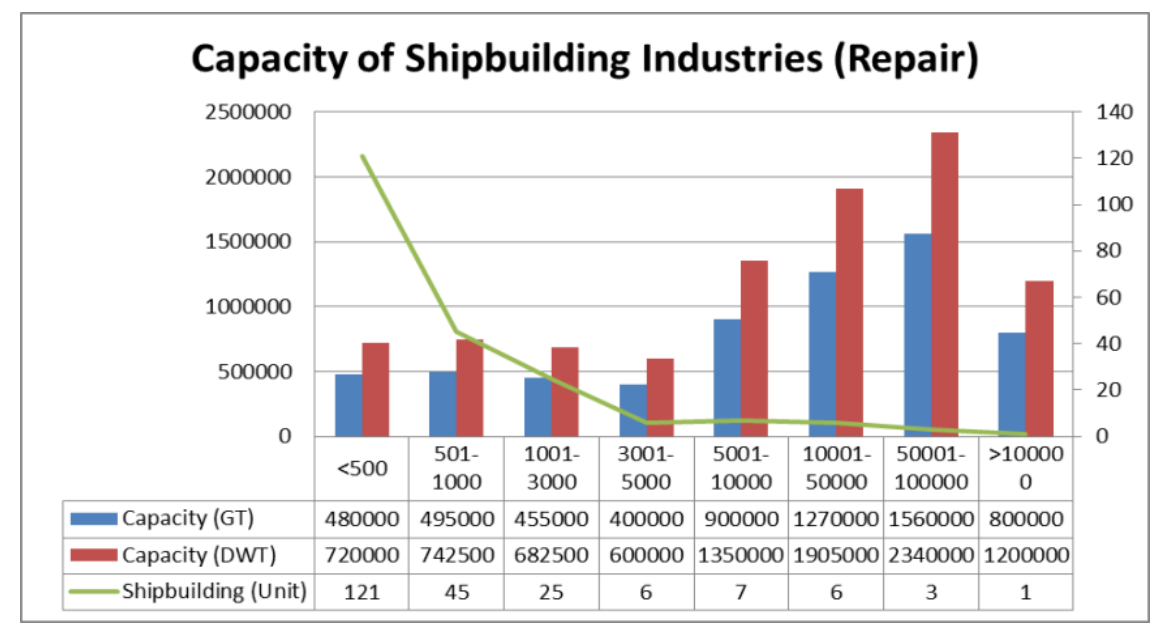

Figure 1: Capacity repair shipyards Industries (Repair) [1]

Based on the Figure 1 and Figure 2, shows that the number of shipyards in Indonesia as many as 250 units (output of 12 million DWT / Year). The amount of this shipyard's ability to grown up the investment potential. Especially shipbuilding and ship repair. But it can do if the shipyard is capable and able to compete with other shipyards.

But, the potential investors cannot do, due to the use of dock space and the competitiveness of shipbuilding in Indonesia is still lacking. This is shown by the $70 \%$ of the market dominated by domestic. So it needs more effort so that the Indonesian shipyard can get an international market.

Thus, studies conducted to analyze improve the competitiveness of shipbuilding in Indonesia. Based on the government's fiscal policy and human resources. The method used to do this research is descriptive literature study and the integrated analysis. The descriptive method approach combines information and literature studies. To improve the competitiveness of shipbuilding industry.

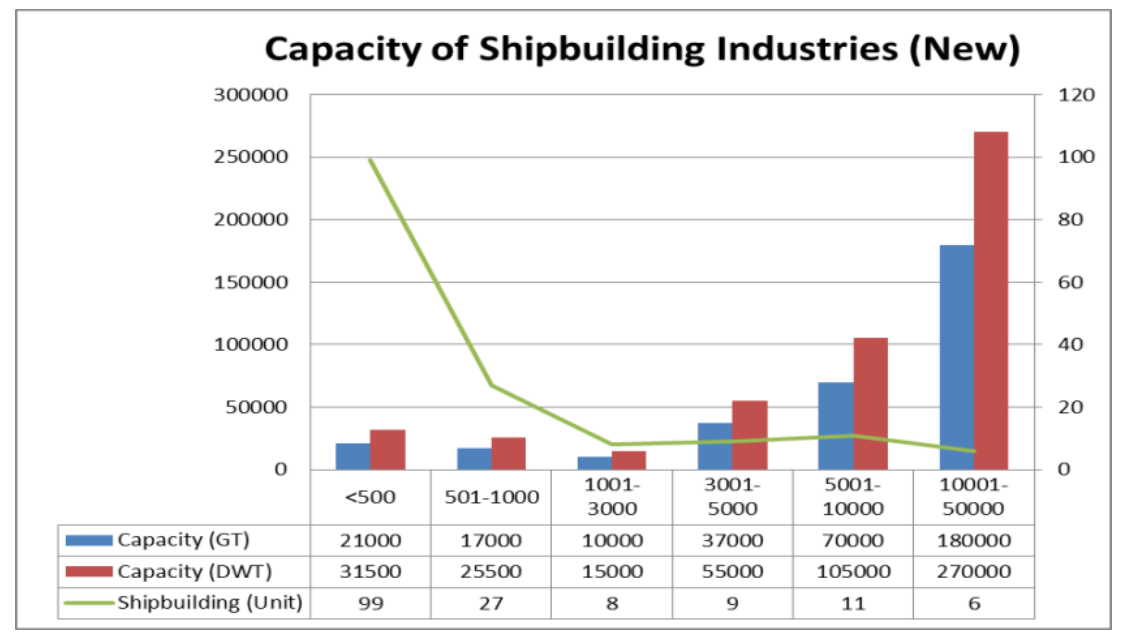

Figure 2: Capacity vessels (new) in Indonesia [1]

\section{Indonesian Shipbuildling conditions}

Indonesian shipyard development from year to year has increased. As shown by the increasing number of national shipyards each year. Although the number of shipyards in Indonesia has 
increased, it not able to push the national shipbuilding industry. Demand from an overseas ship a very small one reason undeveloped national shipyards. In shipbuilding, Indonesia still relies on imported vessels. Due to the ability of Indonesian shipyard in producing new ships is still low, around 3 scrolled 5 ships per year. Noted Indonesian navy in 2012 as many as 11547 units with condition 50\% had an average age of 35 years. From this data show that Indonesia is still weak.

Indonesian shipyard development in 2008 is shown in Table II according to report from Lloyds Register-Fairplay in June 2007. In the table, we can see that Indonesia ranks 21 as one of the world's shipbuilding industry. Even the position of Indonesia is still below other Asian countries, such as Japan, South Korea, China, Taiwan, Vietnam, Philippines.

Table1: The world's shipbuilding industry

\begin{tabular}{|c|c|c|c|c|c|}
\hline \multirow{3}{*}{ No. } & \multirow{3}{*}{ Country } & \multicolumn{2}{|c|}{ quantity Order } & \multicolumn{2}{|c|}{ handover } \\
\hline & & Volume & amount & Volume & amount \\
\hline & & (Million GT) & (Units) & (Million GT) & (Units) \\
\hline 1 & South Korea & 98.436 & 1,820 & 4.772 & 104 \\
\hline 2 & China & 72.055 & 2,445 & 2,470 & 149 \\
\hline 3 & Japan & 61.845 & 1,406 & 4.039 & 128 \\
\hline 4 & Philippines & 4.378 & 106 & 0065 & 2 \\
\hline 5 & German & 4,220 & 196 & 0346 & 17 \\
\hline 6 & Romania & 2,648 & 129 & 0093 & 11 \\
\hline 7 & Vietnamese & 2.622 & 156 & 0007 & 8 \\
\hline 8 & Taiwan & 2,529 & 60 & 0121 & 2 \\
\hline 9 & Italy & 2,360 & 117 & 0155 & 6 \\
\hline 10 & Poland & 2,231 & 120 & 0204 & 11 \\
\hline 11 & Turkey & 2,177 & 319 & 0125 & 25 \\
\hline 12 & Croatia & 1,986 & 65 & 0179 & 8 \\
\hline 13 & Denmark & 1,262 & 18 & 0171 & 1 \\
\hline 14 & India & 1,175 & 184 & 0045 & 5 \\
\hline 15 & Spanish & 0934 & 158 & 0044 & 15 \\
\hline 16 & Finland & 0921 & 11 & 0190 & 2 \\
\hline 17 & Netherlands & 0841 & 282 & 0047 & 26 \\
\hline 18 & France & 0751 & 13 & 0093 & 3 \\
\hline 19 & Russia & 0740 & 89 & 0064 & 10 \\
\hline 20 & United States of America & 0668 & 138 & 0049 & 10 \\
\hline 21 & Indonesia & 0586 & 126 & 0036 & 8 \\
\hline
\end{tabular}

Indonesia's shipbuilding industry has developed, but it cannot compete with other shipyards. The role of the shipbuilding industry to improve the economy needs to support by all parties. Government policy plays an important role in a growth of shipbuilding industry. Most of the smooth operational processes shipbuilding industry affected by government policy.

Besides to government policies, things that must improve its human resources. They have to increase in employee skill, new knowledge, and technology of ship manufacture and repair, 
shipyard management. Human resources are not advanced influence the growth of shipbuilding industry will not grow, ship orders will be late.

\section{Government Fiscal Policy}

Progress and competitiveness of shipbuilding industry need support by the government. The result [2], stated that the government must support the growth of shipyards. And government help in research classifies into two, direct subsidies and indirect subsidies.

The results by Hiroshi [3] about the provision of direct subsidies to ease the burden on corporate loans shipbuilding. Indirect subsidies in the form of tax incentives to reduce the amount of corporation tax, income, fixed asset tax, etc.

Also in the journal [4] states that every country has an active and protective role to protect the shipyards with subsidies to strengthen and improve the competitiveness of the national fleet. Such measures include the provision of direct and indirect subsidies.

The government policy an important role in supporting the growth of shipbuilding industry. The Indonesian government, to support the growth of the shipyard, with the proven issuance of Presidential Instruction No. 52015 about the empowerment of the national shipping industry. In this policy of sabotage tool and plan policies and take measures to empower the national shipping industry, one of which is the shipbuilding industry.

The government's fiscal policy is one of the policies that affect the shipbuilding industry. It affects the price of the domestic vessel. So, the appropriate fiscal policy can increase the rate of growth of Indonesian shipyard.

Table 2: Structure COST Dan Levy Country

\begin{tabular}{|l|c|c|c|}
\hline \multicolumn{1}{|c|}{ Cost } & $\begin{array}{c}\text { Import } \\
\text { Purchase Ship }\end{array}$ & $\begin{array}{c}\text { Production of } \\
\text { the new vessel } \\
\text { (NON FTZ) }\end{array}$ & $\begin{array}{c}\text { Production of } \\
\text { the new vessel } \\
\text { (FTZ) }\end{array}$ \\
\hline Value-added tax & $10 \%$ & $10 \%$ & $10 \%$ \\
\hline Duty on Vessel Components & $0 \%$ & $5 \%-15 \%$ & $0 \%$ \\
\hline income tax & - & $1.5 \%-7.5 \%$ & $1.5 \%-3 \%$ \\
\hline Income Tax (clause 22 imports) & $2.5 \%-7.5 \%$ & $2.5 \%-7.5 \%$ & $0 \%$ \\
\hline $\begin{array}{l}\text { The number of countries } \\
\text { Chargespasal }\end{array}$ & $12.5 \%-17.5 \%$ & $19 \%-30.5 \%$ & $1.5 \%-3 \%$ \\
\hline
\end{tabular}

\subsection{Value Added Tax (VAT)}

VAT is a tax levied on taxable goods delivery (BKP) and taxable services (JKP). These are costs not directly, so it must be borne by the seller. Fee added to the cost of goods and services traded. VAT is also charged on goods imported from outside Indonesia.

Taxation, there are some rules on taxation and customs, one of which is the Government Regulation No. 38 of 2003 on the import and or Delivery of Certain Taxable Goods and or Delivery of Certain Taxable Services are exempt from Value Added Tax (VAT). Which lowers costs passenger transport logistics and transport of goods. The negative impact, 10\% VAT is chargeable at the time of the production process and is the responsibility of the shipbuilding industry. This resulted in the selling price of a domestic vessel to be more expensive than the price of imported vessels. While the costs of the vessel import VAT zero (0\%). For this reason, creating preference companies prefer to buy imported vessels. 
Evaluation of the implementation of VAT in the shipbuilding industry should be a review. VAT exemption on the shipbuilding industry can improve the competitiveness of domestic vessel so that production will increase. Besides, the company's cash flow does not need to be divided to pay VAT. Local ship prices to be cheaper than the imported vessels. 10\% VAT exemption has done by the government, but this policy only applies in the zone FZT area (Batam and surrounding areas). It should also apply to areas outside Batam so that shipyards can compete. With the abolition of VAT $10 \%$ for shipyards throughout Indonesia, the selling price of the new vessel to be cheaper and low production costs.

Determination of 10\% VAT removal policies for shipbuilding industry throughout Indonesia into something that must be considered by the government. Due to the implementation of these policies could have a direct impact on the shipbuilding industry. So that the shipyard industries can compete with shipyards in other countries.

\subsection{Duty Ship Components}

Import duties, according to the Directorate General of Customs and Excise (DGCE) is the state levies imposed on imported goods. In this division is divided into two :

- Valorum Duty is the rate of duties charged based on a certain percentage. The amount of duty is calculated by multiplying the percentage of the price of goods.

- Specific Duty is a an import duty charged based on certain rupiah value of goods quantity. The amount of duty is calculated by multiplying the tariff by the amount of imported goods.

The components used to produce ships in Indonesia is still dominated by imported components because of the unavailability of components produced.

Based on the division of kind of duty to duty component imposed on the shipyard Advolarum level. To import components borne by the government under Ministry of Finance Regulation No. 57 / PMK.011 / 2013 about Customs entry of goods and materials for repairing or shipbuilding, 160 kinds of imported goods, such as MGP, Ship Steel Plate, Pipe for the Shipbuilding, etc. other. In the construction of new ships, the import component is an essential component that cannot produce in the country. Components include: Combat Management System (CMS) consists of software, sensors Detection Equipment and Electronic Systems. Electrical \& Electronics and Machinery.

The imposition of import charges levied on component parts shipyard vessel causing pric es to be more expensive and profits earned by the shipyard becomes smaller. This is due to the domestic component level (DCL) in the shipbuilding industry of about $20 \%$. So, the import restrictions and the charging component cannot create national shipyards to compete with foreign shipyards.

The government's policy on BMDTP (Government Borne Task) has not been effective, based on Edi Slamet in 2016 [5]. BMTDP uses research literature study and focuses group discussion methods, indicating that BMDTP is unsuitable for use in Indonesia as a tax policy because it is not under the nature of the shipping industry business in Indonesia, which is a work order. Thus, the government's policy is more precise with $0 \%$ Duty facility to import of components not produced in Indonesia or insufficient production volume demand for Indonesian shipyard industry components.

$0 \%$ Obligation is one of the policies that must be applied by the Indonesian government to put in place the policy can influence on the decrease of production cost in general. Lower production costs will drive the sale price of ships cheaper. The price is cheaper, will be able to increase productivity, finally able to increase profits. Increased profits will be able to maintain the growth drive of Indonesia's shipyard industry. 


\subsection{Tax allowance}

Indonesia is vast ocean areas that have not maximized the potential of foreign exchange by the state. Therefore, Indonesia seeks to enhance the role of the national shipbuilding industry. However, until now the national shipbuilding is still in demand by national and international market share. One reason is the lacks of the government facilities and incentives relating to Income Tax (VAT) to be applied by the Indonesian capital.

Income Tax policy is governed by the Republic of Indonesia Government Regulation No. 52, the year 2011 about Income Tax Facilities for Investment in Certain Business Fields and/or in Certain Regions. (Clause 2 (two) paragraph (2) the Indonesian Government Regulation No. 52 of 2011) Imposition of Income Tax Facility for Investment Industries shipyard as follows:

a) The decrease in net income of $30 \%$ of the investment amount, charged for six (6) years respectively at $5 \%$ per year.

b) Accelerated depreciation and amortization, as follows:

c) The imposition of income tax on dividends paid to foreign tax subject by $10 \%$, or lower rates based taxation agreement in force; and.

d) Compensation for losses that are older than 5 years, but not more than 10 years.

The Government issued the latest policies on PPH Minister of Finance Regulation No. 1592015 About Provision for Corporate Income Tax Reduction Facility. Incentives abolition of income tax (PPH) agency or company by $10 \%-100 \%$. This incentive gives to industry pioneer in Indonesia. Which includes 9 enterprises, one of which is the shipbuilding industry. The government's fiscal policy as a long-awaited by employer's shipyard. So on improve the productivity of national shipyards.

But, implementation of these policies has not been up to run by the Indonesian government. Recommendation of fiscal policy on the PPH should include all shipyards in Indonesia. Most of the old shipyard, so the company PPH can reduce even eliminated. Therefore, the government must implement the fiscal policy and do not forget to evaluate on an ongoing basis so that the fiscal policy of PPH can be useful for the shipyard industry.

\section{Human Resources}

In the world of industry, the human factor is a major asset to the company. Shipbuilding industry that has experienced human resources as well as having the knowledge and technology development and repair of ships, can make the shipyard industry forward and succeed.

Indonesia according to World Competitiveness Report ranks the lowest of all countries surveyed. Under Singapore (8), Malaysia (34), Philippines (38), and Thailand (40). With the condition of Human Resources. Thus, it is necessary to develop human resources to increase the productivity of the shipbuilding industry.

One of the main problems with improving HR Indonesia is the misallocation of Human Resource. Many labors and the best college graduates are not under the program of study or knowledge has, for example, shipping graduate working as a staff in the bank. In addition, competency-based training and development have not been applied in Indonesia.

Therefore, support for human resource capacity building programs is helpful in enhancing the competitiveness of the shipping industry. Increased shipping industry judged on three sides, a cost advantage, differentiation advantage, and production capabilities faster. 


\subsection{Manpower Planning (MPP)}

Man Power Planning is one of the efforts made to improve the quality of Human Resources. The preparation of the necessary labor must meet the criteria of SAK (Skill, Attitude, and Knowledge). So that labor is owned by shipbuilding industry under that is needed. This can increase the productivity of industries that can increase the competitiveness of shipbuilding industry in Indonesia. The steps required to put in place the MPP under Table IV.

Table 3: Step Manpower Planning

\begin{tabular}{|c|l|l|l|}
\hline No & \multicolumn{1}{|c|}{ Step } & \multicolumn{1}{c|}{ Activity } & \multicolumn{1}{c|}{ Event Details } \\
\hline 1 & Strategy & Assessment Strategies & $\begin{array}{l}\text { Reviewing the strategy and plans for } \\
\text { HR }\end{array}$ \\
\hline 2 & Data collection & $\begin{array}{l}\text { Mapping (Existing } \\
\text { Conditions) }\end{array}$ & $\begin{array}{l}\text { Performing a SWOT analysis } \\
\text { Perform analysis of supply / demand }\end{array}$ \\
\hline 3 & Data analysis & Gap analysis & $\begin{array}{l}\text { Comparing the current skill needs } \\
\text { Gap identify staffing }\end{array}$ \\
\hline 4 & Implementation & Gap closure strategy & $\begin{array}{l}\text { Recruitment, Selection, training, } \\
\text { appraisal }\end{array}$ \\
\hline 5 & Evaluation & Review and Assessment & Develop HR planning advice \\
\hline
\end{tabular}

\subsection{Transfer of Technology (TOT)}

Transfer of Technology is one shipyard efforts made to improve its human resources by working with the shipyard from outside Indonesia. This is done by sending the shipyard workers to other shipyards to learn the knowledge and technology to build the ship.

This has been applied by most shipyards in Indonesia. One of them, PT. PAL Indonesia has worked with another shipyard. Cooperation with DSN is done to build the PKR ship. Besides, the cooperation is jointly conducted with Daewo to produce submarines.

\section{Conslusion}

Increasing Indonesia's shipyard competitiveness must be done by all elements. The Indonesian government must play an active role in issuing a fiscal policy. Appropriate fiscal policy, such as VAT 0\%, 0\% import duty, tax and more tax benefits can be applied to the shipyard. Appropriate fiscal policy can provide a positive influence shipyard in Indonesia.

Besides to government participation through appropriate fiscal policy. The Indonesian shipyard improves the capabilities and expertise of its human resources. Application of MPP and TOT is an important method to improve human resources. The effect of enhancing human resource expertise and encouraging ship production on schedule. So, Government and shipyards support is needed to increase the competitiveness of Indonesian shipyard.

\section{References}

[1] Industrial Ministry and IPERINDO, "Capacity of National Shipbuilding Industry", 2017.

[2] Oda, M, "Changing face of the competitive structure in the liner shipping sector," J. Amrit. Ind. Res. 26, 1997, p. $30-42$.

[3] Hirosi, YK, “New movments help delivery for 21 centuries, ” J. Shipp. Ind. Res. 390, 1998, p. 1-24. 
[4] Good, OS, “National Fleet Upgrade Protection Scheme International Competitiveness Seoul,” Korea Maritime Institute, Korea, 1993.

[5]Liping Jiang, Erik Bastiansen, Siri P. Strandenes, “The International Competitiveness of China's shipbuilding industry," Tansportation Research Part E 60, 2013, pp. 39-48.

[6] Edi Slamet, Haula Kosdiana, Sunaryo, Maria RUD Tambunan, Inayati, “Konstruksi Ulang Kebijakan Fasilitas Bea Masuk Untuk Meningkatkan Produktifitas Industri Galangan Kapal di Indonesia,” Simposium Jaringan Perguruan Tinggi untuk Perkembangan Infrastruktur Indonesia. Jakarta, 2016, pp. 208-215.

[7] Lutfim Cania, "The Impact of Strategic Human Resources Management on Organizational Performance," Economia Seria Management, vol. 17, issue 2, Albania, 2014.

[8] Ika Rihana, "Pengembangan Kualitas Sumber Daya Manusia VS Daya Saing Global," Jurnal Profit, vol.6 no.1, June, 2012.

[9]Heung-Jun Jeong, "The Effect of Globalization on Human Resource Management, Unions and Flexibility in South Korea, ” Korea: Korea Unversity. Labour Institute, 2012. 